\title{
Stroke mimicking acute myocardial infarction
}

\section{Peter Michael Edward Slade}

Department of Geriatric Medicine, Abertawe Bro Morgannwg University Health Board, Swansea, UK

\section{Correspondence to} Dr Peter Michael Edward Slade, pslade@doctors.org.uk

\section{DESCRIPTION}

An 87-year-old man was admitted to the emergency department acutely collapsed with a dense right hemiparesis. He had been found by his relatives after having been last seen $24 \mathrm{~h}$ earlier. He was found on the floor, with evidence of vomiting, and was not vocalising or moving his right limbs. He had a history of hypertension and was taking candesartan, aspirin and simvastatin. There was no family history of ischaemic heart disease or stroke.

Initial investigations revealed a raised serum troponin $\mathrm{T}$ of $705 \mathrm{ng} / \mathrm{L}$ and ECG revealed ST segment elevation in chest leads 1-5 (figure 1). CT scan of the brain showed an extensive left-sided intracerebral haemorrhage centred on the left thalamus with intraventricular extension of blood into both lateral ventricles (figure 2). Further ECGs established widespread $\mathrm{T}$ wave inversion in the lateral leads. An echocardiogram revealed wellpreserved systolic function and no regional wall motion abnormalities. After considering the differential and most likely diagnosis with the risks and benefits of management such as antiplatelet therapy, the patient with an acute intracerebral haemorrhage was managed conservatively in the acute stroke ward.

Raised troponin occurs frequently in patients with acute stroke. ECG changes are common in

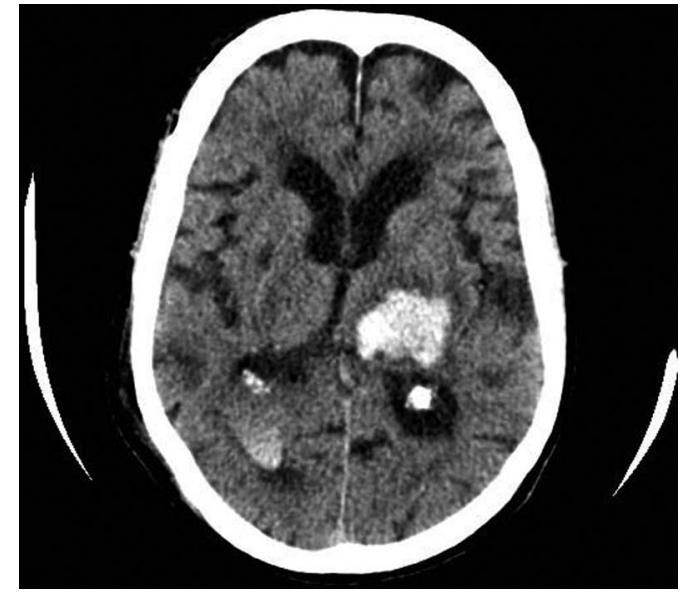

Figure 2 Non-contrast CT demonstrating intracerebral haemorrhage.

stroke and include ischaemic-like changes and QT prolongation. They are more common in patients with pre-existing heart disease and a troponin rise predicts a poor outcome. ${ }^{12}$ Making the correct diagnosis is imperative in such patients and these investigation results pose challenging management questions.

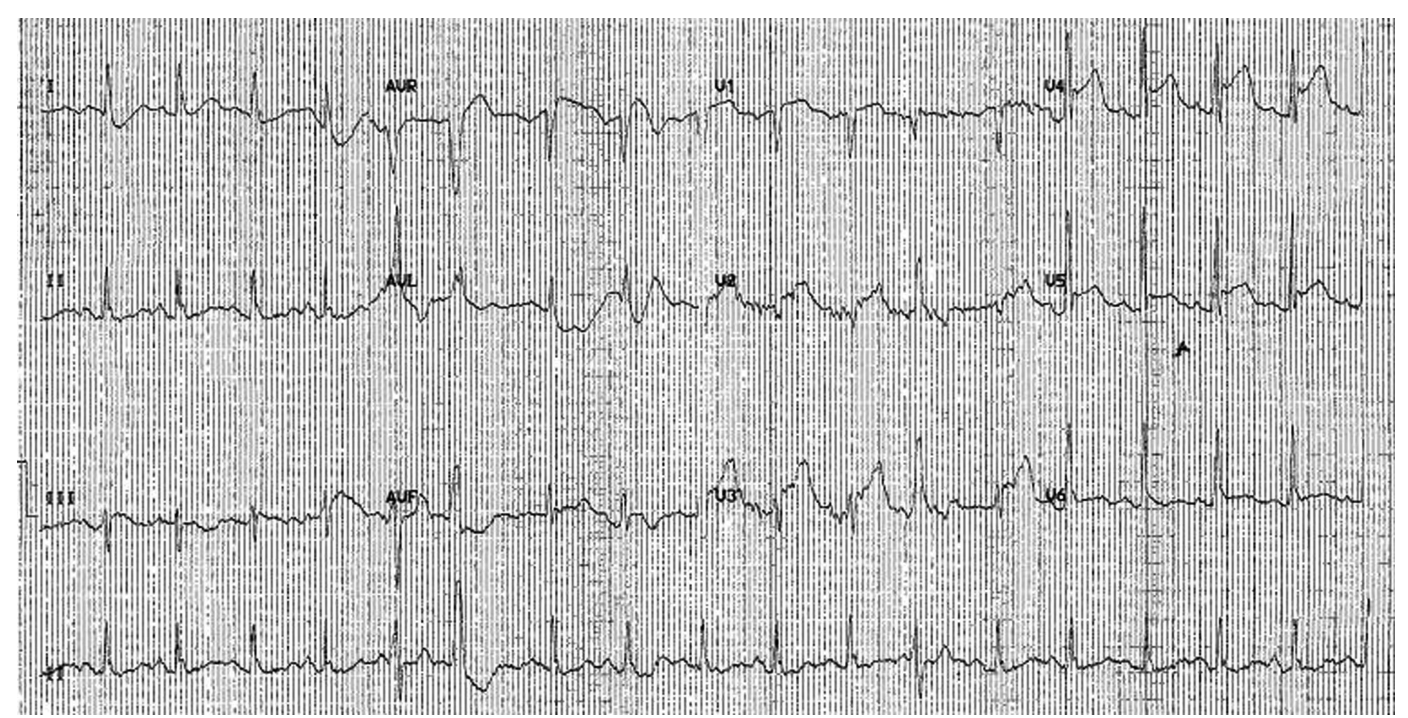

Figure 1 ECG demonstrating ST elevation in chest leads 1-5. 


\section{Learning points}

- Acute stroke is a cause of raised serum troponin and ST elevation on ECG and therefore may mimic acute myocardial infarction.

- Investigation results should be taken into context with the clinical situation and not in isolation. Management should be based on clinical history, examination and investigation results.

- A rise in troponin due to acute stroke is associated with a poor outcome.
Competing interests None.

Patient consent Obtained.

Provenance and peer review Not commissioned; externally peer reviewed.

\section{REFERENCES}

1 Fure B, Bruun Wyller T, Thommessen B. Electrocardiographic and troponin T changes in acute ischaemic stroke. J Intern Med 2006;259:592-7.

2 Khechinashvili G, Asplund K. Electrocardiographic changes in patients with acute stroke: a systematic review. Cerebrovasc Dis 2002;14:67-76.

Copyright 2013 BMJ Publishing Group. All rights reserved. For permission to reuse any of this content visit http://group.bmj.com/group/rights-licensing/permissions.

BMJ Case Report Fellows may re-use this article for personal use and teaching without any further permission.

Become a Fellow of BMJ Case Reports today and you can:

- Submit as many cases as you like

- Enjoy fast sympathetic peer review and rapid publication of accepted articles

- Access all the published articles

- Re-use any of the published material for personal use and teaching without further permission

For information on Institutional Fellowships contact consortiasales@bmjgroup.com

Visit casereports.bmj.com for more articles like this and to become a Fellow 